\title{
Visões do agregado em Machado de Assis
}

Flávia Gieseler de Assis

Curso: Mestrado em Sociologia

Data da defesa: 19 de dezembro de 2007

Orientador: Prof. Dr. João Gabriel Lima Cruz Teixeira

\section{Resumo}

Nos romances de Machado de Assis aparece com freqüência a figura do agregado - indivíduo livre e pobre que necessitava viver à sombra de um senhor para a manutenção de sua existência. $\mathrm{Na}$ sociedade brasileira do século XIX, o modo de produção escravista e monocultor tirava do homem livre praticamente todas as possibilidades de integração à produção mercantil. Sem ter como se sustentar, e vivendo em um país em que o domínio dos senhores sobrepujava a impessoalidade das leis, o vínculo criado com estes senhores era, muitas vezes, a única forma que esse homem possuía para garantir a sobrevivência. A sua situação frágil privava-o, muitas vezes, de um existir autônomo. A proximidade e quase familiaridade com o senhor, colocava-o em uma situação ambígua: ao mesmo tempo em que tinha reconhecidos seus predicados humanos, era-lhe atribuída a desclassificação social. As ambigüidades da vida agregada possibilitam uma multiplicidade de ações e acomodações que são bastante exploradas por Machado de Assis em seus romances.

Utilizando a obra de Machado de Assis, este trabalho buscou explorar as possibilidades de articulação entre essas duas esferas sociais. A estrutura histórica forjou o autoritário pensamento senhorial e as doutrinas do além-mar (positivismo, realismo, naturalismo), 
ajudaram a validar sua crença de superioridade. Ao agregado - que não podia contar com as normas impessoais -, restou a tentativa de sobreviver sem poder contestar diretamente uma ordem rigidamente hierarquizada. Imobilizado por essa hierarquia, ele encontraria na manipulação da vontade senhorial sua única alternativa para alcançar seus interesses.

Se as doutrinas cientificistas da época - as mesmas usadas como justificativa de dominação por parte dos senhores - percebiam o indivíduo de forma animalesca e, portanto, descaracterizavam o agregado como um agente social, Machado de Assis o resgatava como ser moral, permitindo-lhe o direito ao cálculo e à perfídia. Essa era mais uma sutileza do pessimismo irônico de Machado de Assis: a capacidade de humanizar por meio da relativização. Machado de Assis não negou os indivíduos. Sua obra mostrou que as lutas pelo poder, por interesses pessoais e pela autonomia se perpetuam, posto que a sociedade é rigidamente hierarquizada. Afinal, antes de ser hierárquica, ela é dinâmica, seja nos romances de Machado de Assis, seja nos conflitos da vida real.

Palavras-chave: pensamento social brasileiro, cultura do favor, literatura. 